\title{
A SURVEY STUDY ON DURRIES OF NAKODAR, PUNJAB (INDIA)
}

\section{DR.SIMERJEETKAUR ${ }^{1} \&$ MISS RUPALI ${ }^{2}$}

${ }^{1}$ Assistant Professor in fashion designing, P.G. department of Fashion Designing, Maha Vidyalaya, Jalandhar, Punjab

${ }^{2}$ Research Scholar in fashion designing, P.G. department of Fashion Designing Kanya, Kanya Maha Vidyalaya, Jalandhar, Punjab

\section{ABSTRACT}

In India has a rich and diverse tradition in the field of textile. It is perhaps the world's oldest textile tradition. MostIndian flat weaves are known as Durries and these are made entirely from cotton.Durries are also used as bedcovers and on walls as form of decoration. This study is an attempt to find out the design techniques in Durries. This study was conduct in Nakodar (Punjab). Data was collected by interview cum survey method from 30 respondents in Nakodar was analysed and tabulated. Itis found that majority of respondents were used recently developed designs and 23.4 per cent respondents were used two decades old designs and very few 16.6 per cent respondents were used a decade old designs to making Durries.

KEYWORDS: Durries, prevailing design techniques and cost.

Received: Nov 07, 2020; Accepted: Nov 27, 2020; Published: Dec 03, 2020; Paper Id.: IJTFTOCT20201

\section{INTRODUCTION}

In Indian flat weaves are known as Durries and these are made entirely from cotton. Indian textile was reputed all over the world and admired for their beauty, design and texture. A variety of motifs like creepers, flowers, birds, animals and human forms are integrated in a single design. Parrots, peacocks, lions and doves along with trees and flowers are an essential part of the design in carpets. These Durries are made from yarn produced from cotton after the processing and weaving of yarn. At one time, the process of yarn making, dying and weaving was the preserve of traditional handloom weavers who migrated from Sialkot in Pakistan after partition in 1947. However, the lackadaisical attitude of the successive Punjab governments towards this cottage industry has led to large scale marginalization of the weaver community settled inNakodar.

Indian textile is embellished, enhanced, decorated and given its character through various modes and techniques. The most significant ones are printing and painting, weaving, embroidery and tie and dye. Indian Durries and floor coverings are world famous for their unique designs. They are beingproduced in India for over 5,000 years. The techniques of Durries weaving can be seen in its most primitive form in the villages of Punjab, Rajasthan, and Haryana where girls are normally put to the task at an early age so that they can prepare rugs that will form part of their trousseau

\section{AIMS AND OBJECTIVES}

- To survey the existing product in Nakodar Durriesweaving.

- To study the prevailing designing techniques ofDurries. 
- To calculate the cost of Durriesproduction.

\section{DELIMITATIONS}

Limitations of the processors are: -

- To survey work was carried out only inNakodar.

- The study was limited to 30 craftsmen who related to Durriescrafts.

\section{METHODOLOGY}

Survey, interview, questionnaire and observation methods were selected for conducting this study. Random sampling technique was used to select 30 craftsmen from Nakodar (Punjab). The raw data collected and classified on the basis of respondents, coded (in the form of frequencies) and tabulated (in percentage) these were presented in the form of graphs and tables.

\section{REVIEW OF LITERATURE}

Beazley. M (1996) described thatthecotton Durries were not only made on simple village looms but also in commercial and prison workshops throughout India. Few pieces can compare with the beauty and technical merit of this example from the late $19^{\text {th }}$ century, the colouring of which suggests that it was made in Agra or Amritsar.

Sidhu (1997) concluded that traditional, geometrical, stylized motifs were used for Durries designs. Unit owners selected the motifs on the basis of popularity and attractiveness. The designs were taken from different articles like curtains, sheets and from imagination.

Jayashankar (2001) mentioned that master weavers are mostly using modern designs for Durries and traditional looms, designs for carpets.Majorityofthe consumers preferred mediumsize in average cost, smooth texture, bright lustre, heavy thickness and bright colours for both Durriesandcarpets. Consumersingeneralpreferredcotton, jute Durries which arewoven in modern designs and wool carpets, which arewoven in traditional designs. Clarityand colourcombinationswhilepurchasing Durriesandcarpetsbutdoes not check the place of its manufacturing. Majority of the consumers reported that both Durries and carpets had good colour fastness and good durability.

Anonymous (2017) reported that woven rugs are created or woven on looms. Weaving on loom is the oldest known rug weaving technique to make attractive designs and patterns. Because of the use of hand loomed rugs the same can be more expensive than machine made carpets. It takes many months to weave one rug according to size, knots, material anddesigns.

Ahuja S. (2019)reported that traditional flat woven Indian Durries have long been overshadowed by luxuriant Mughal pile carpets. The Durries were used by commonersand royalty alike: at its simplest, it was a multi-purpose textile used as floor covering, bedding or packaging, while atits most elaborate, it was woven with the finest fibres and enhanced by gold wrapped threads and it graced the places of royalty. Durries also introduces the weavers of Rajasthan and Uttar Pradesh and is guide to the Durries many stages of development from the selection and dyeing of yarn to the actual processes of weaving, washing and finishing. 


\section{RESULT AND DISCUSSIONS}

1. Source of income: - Cent per cent respondents said that their source of income was only manufacturing of Durries or not anyother.

2 Initiation into this work: It was seen that most of the respondents initiated this work right from their young age and gradually mastered this art throughchildhood.

3. Special training for making a Durries craft: - It is clearly described that 50 per cent respondents attended special training for Durries craft but 50 per cent respondents never attended any special training for Durries craft. Some craftsmen acquired Durries craft from family traditional work. They never felt need for any training in this craft. Some respondents were taken training from government skillcentres.

4. Type of business: - It revealed that maximum 96.7 per cent respondents were belongs to whole time of their business but very few 3.3 per cent respondents were belonging to part time of theirbusiness.

\section{5) Learning process}

Table 1: Distribution of Respondents on the basis of their learning process $(n=30)$

\begin{tabular}{|l|l|l|l|}
\hline S.No. & \multicolumn{1}{|c|}{ Variables } & \multicolumn{1}{|c|}{ Respondents } & \multicolumn{1}{c|}{ Percentage (\%) } \\
\hline 1. & Forefathers & 20 & $66.7 \%$ \\
\hline 2. & Others & 10 & $33.3 \%$ \\
\hline & Total & $\mathbf{3 0}$ & $\mathbf{1 0 0 . 0 0}$ \\
\hline
\end{tabular}

Table 1 shows that 66.7 per cent respondents learnt Durries craft from forefathers experience and few respondents i.e. 33.3 per cent were not interested to tell from where they learnt Durries craft.

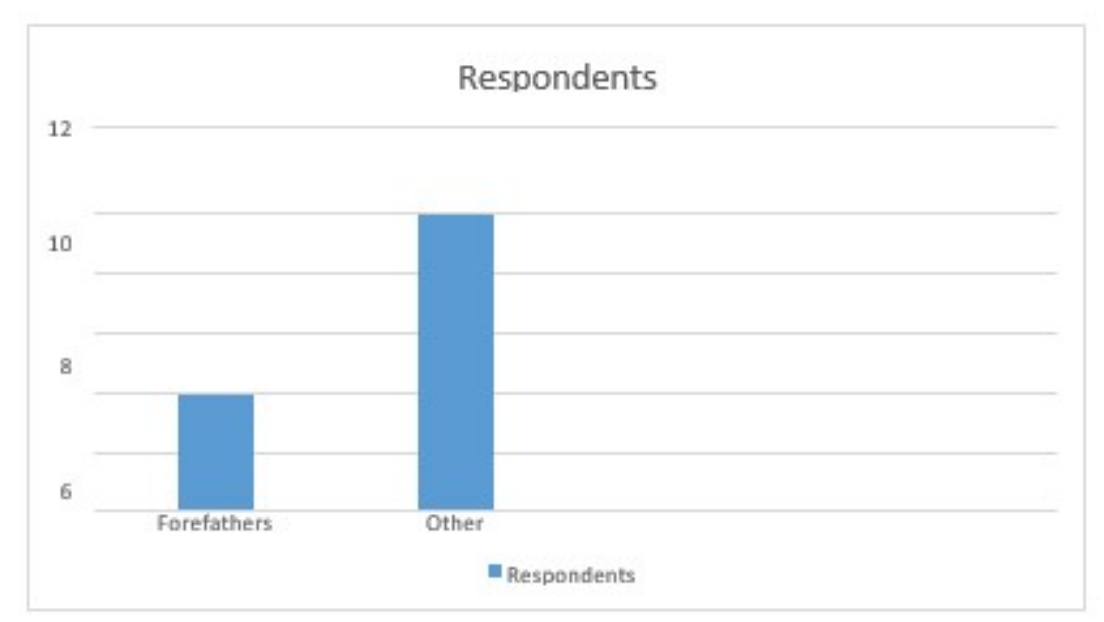

Figure 1: Distribution of Respondents on the basis to their learning process

\section{6) Working hours}


Table 2: Distribution of Respondents on the basis to their working hours $(n=30)$

\begin{tabular}{|l|l|l|l|}
\hline \multicolumn{1}{|c|}{ S.No. } & \multicolumn{1}{|c|}{ Variables } & \multicolumn{1}{|c|}{ Respondents } & \multicolumn{1}{c|}{ Percentage (\%) } \\
\hline 1. & $4-6$ hours & 0 & $0 \%$ \\
\hline 2. & $6-8$ hours & 1 & $3.3 \%$ \\
\hline 3. & $8-10$ hours & 22 & $73.3 \%$ \\
\hline 4. & $10-12$ hours & 7 & $23.4 \%$ \\
\hline & Total & $\mathbf{3 0}$ & $\mathbf{1 0 0 . 0 0}$ \\
\hline
\end{tabular}

Table 2 depicts that in Nakodar there were 73.3 per cent respondents who spend 8-10 hours every day for making Durries and 23.4 per cent respondents spend 10-12 hours every day for making Durries but only few 3.3 per cent respondents were spend 6-8 hours every day for making Durries.

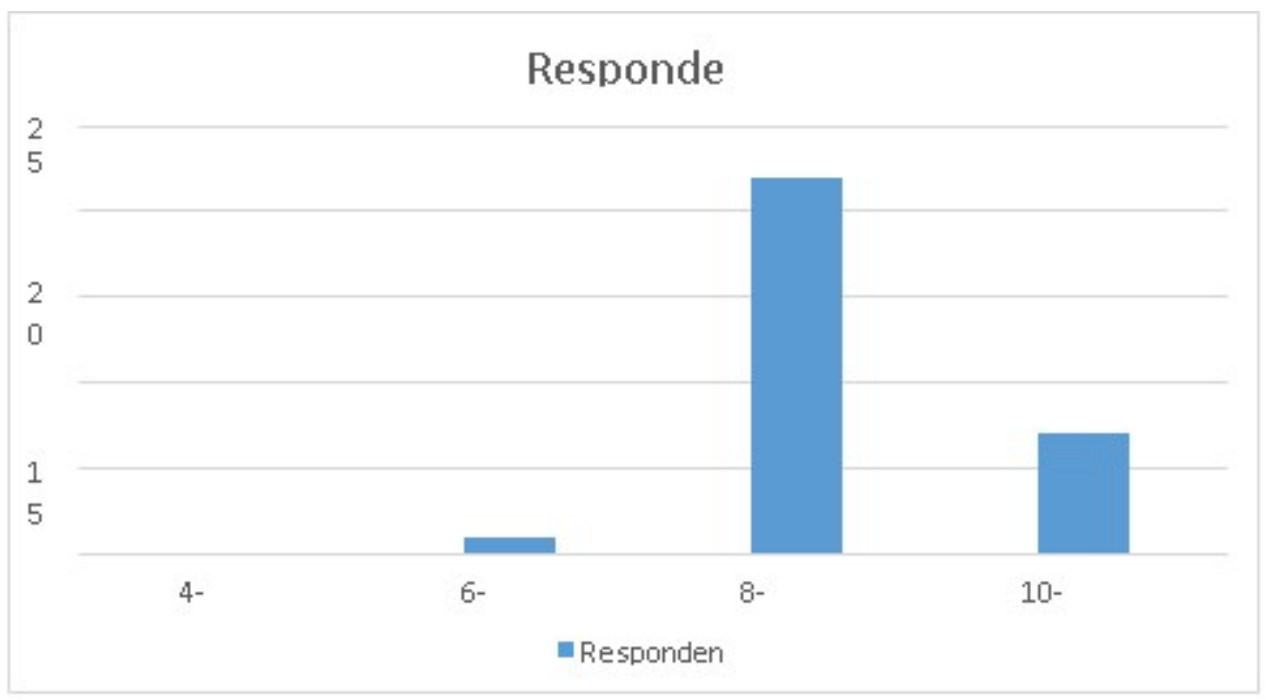

Figure 2: Distribution of Respondents on the basis of their working hours

7) Time Spent on Making Durries

Table 3: Distribution of Respondents on the basis to their time spend on making Durries $(\mathbf{n}=\mathbf{3 0})$

\begin{tabular}{|l|l|l|l|}
\hline \multicolumn{1}{|c|}{ S.No. } & \multicolumn{1}{|c|}{ Variables } & \multicolumn{1}{c|}{ Respondents } & \multicolumn{1}{c|}{ Percentage (\%) } \\
\hline 1. & 1 hour & 5 & $16.7 \%$ \\
\hline 2. & 2 hour & 25 & $83.3 \%$ \\
\hline & Total & $\mathbf{3 0}$ & $\mathbf{1 0 0 . 0 0}$ \\
\hline
\end{tabular}

Table 3 shows that majority of 83.3 per cent respondents spend 2 hours for making Durries but only 16.7 per cent respondents spend 1 hour for making Durries. 


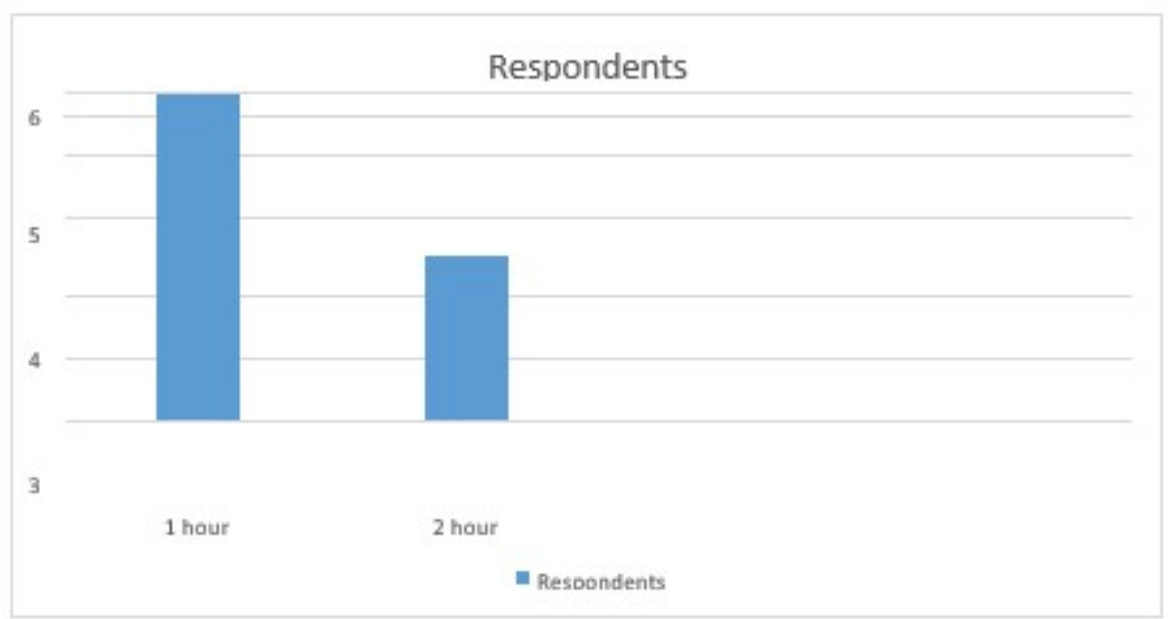

Figure 3: Distribution of Respondents on the basis to their time spend on making Durries

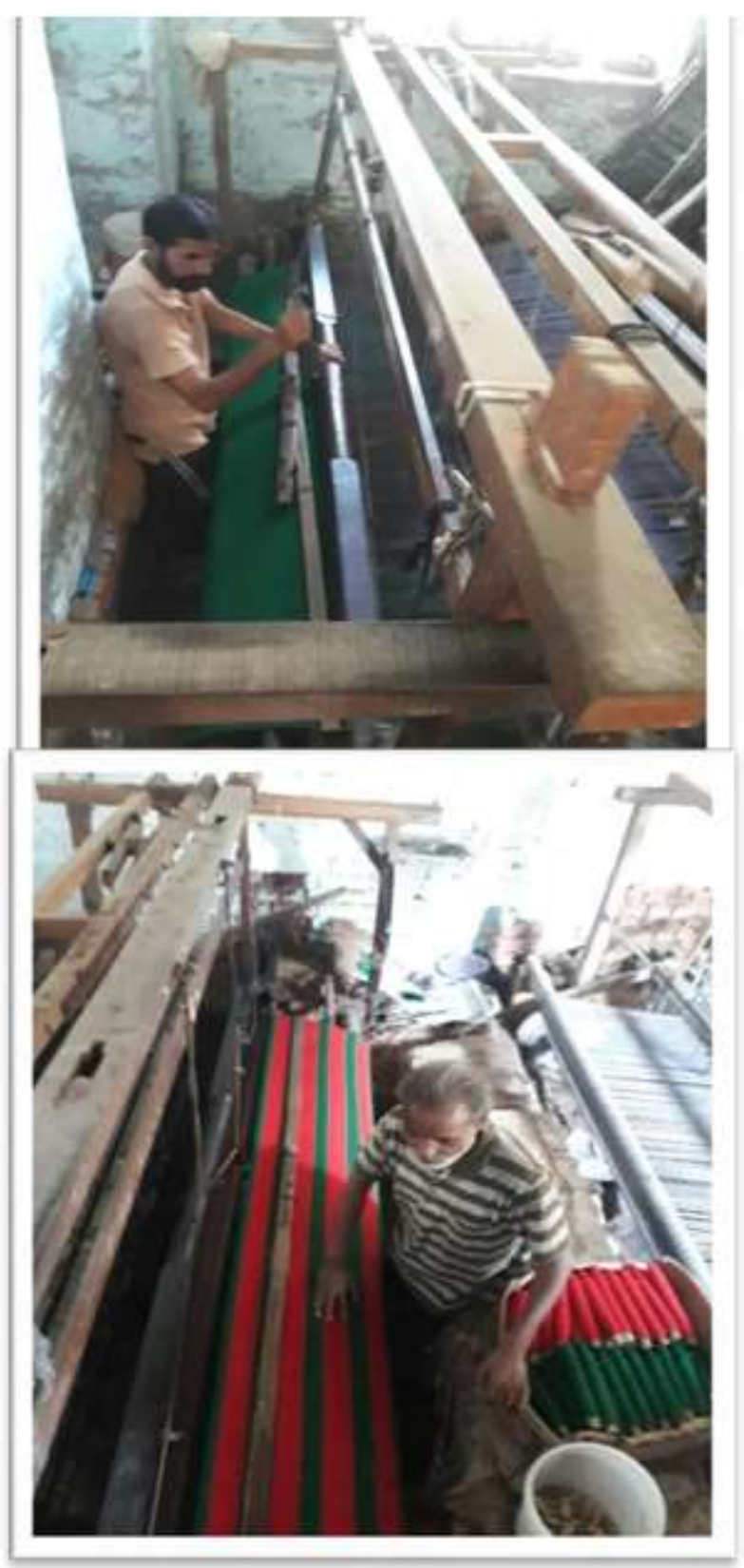




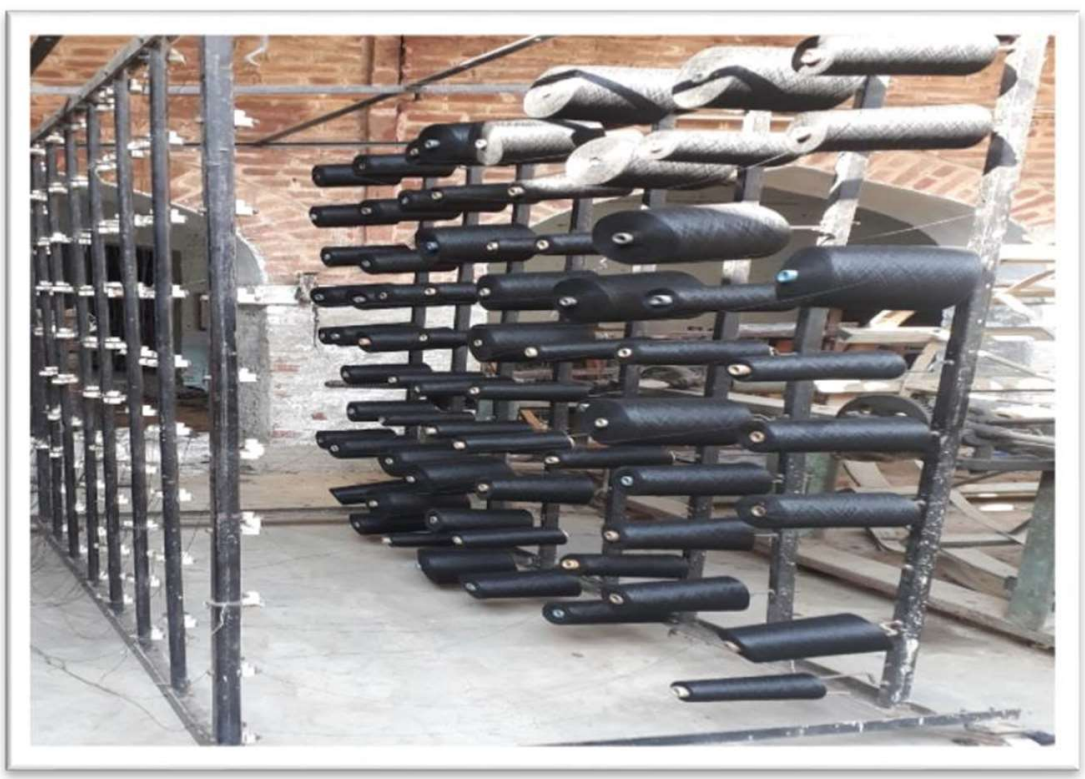

PLATE: 1 Process of making Durries

8) Use of design: -

Table 4: Distribution of Respondents on the basis to their use of designs

\begin{tabular}{|c|c|c|c|}
\hline S.No. & Variables & Respondents & Percentage (\%) \\
\hline 1. & Yes & 10 & $33.3 \%$ \\
\hline 2. & No & 20 & $66.7 \%$ \\
\hline & Total & 30 & 100.00 \\
\hline
\end{tabular}

Table 4 shows that maximum 66.7 per cent respondents said they were not used designs but 33.3 per cent respondents said that they were used any design for making Durries. 


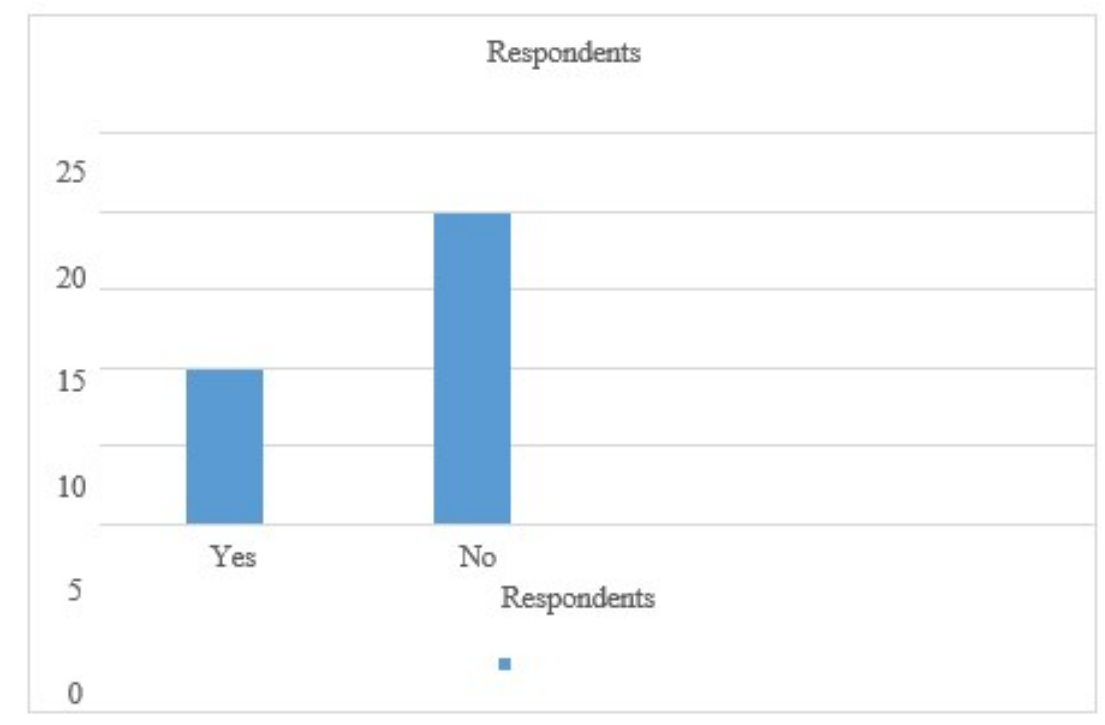

Figure 4: Distribution of Respondents on the basis to their use of designs

Table 5: Distribution of Respondents on the basis to showcase their design $(\mathbf{n}=\mathbf{3 0})$

\begin{tabular}{|l|l|l|l|}
\hline \multicolumn{1}{|c|}{ S.No. } & \multicolumn{1}{|c|}{ Variables } & \multicolumn{1}{c|}{ Respondents } & \multicolumn{1}{c|}{ Percentage (\%) } \\
\hline 1. & Samples & 21 & $70 \%$ \\
\hline 2. & Booklets & 3 & $10 \%$ \\
\hline 3. & Soft copies & 1 & $3.3 \%$ \\
\hline 4. & Any other & 5 & $16.7 \%$ \\
\hline & Total & $\mathbf{3 0}$ & $\mathbf{1 0 0 . 0 0}$ \\
\hline
\end{tabular}

Table 5 clearly depicts that maximum 70 per cent respondents said that they showcase samples as a design and 10 per cent respondents said that they used booklets to showcase their design and only 3.3 per cent respondents said that they used soft copies as a design to showcase but 16.7 per cent respondents were not willing to answer this question.

10) Designs related to Durries: -It said that 90 per cent respondents said that they used booklets as designs related to Durries but only few 10 per cent respondents said that they were used soft copies as a designs related toDurries.

11) Type of Design list: -It depicts that maximum 73.3 per cent respondents were used market design list and 16.6 per cent respondents were used own creation design list and few 6.7 per cent respondents were used forefathers design list but very few 3.3 per cent respondents were not interested to tell which type of design list they wereused.

12) How old design list: -Table 18 described that majority of 79 per cent respondents were used recently developed designs and 23.4 per cent respondents were used two decades old designsand very few 16.6 per cent respondents were used a decade old designs to makingDurries. 
Table 6: Distribution of Respondents on the basis to their type of pattern

\begin{tabular}{|l|l|l|l|}
\hline S.No. & Variables & Respondents & Percentage (\%) \\
\hline 1. & Overall pattern & 29 & $96.7 \%$ \\
\hline 2. & Central pattern & 1 & $3.3 \%$ \\
\hline 3. & Border pattern & 0 & $0 \%$ \\
\hline & Total & $\mathbf{3 0}$ & $\mathbf{1 0 0 . 0 0}$ \\
\hline
\end{tabular}

Above Table 6 indicates that maximum 96.7 per cent respondents said they used overall pattern in Durries and very few 3.3 per cent respondents said that they were used central pattern in Durries.

14) Calculation of price for Durries: -It is described that cent per cent respondents said they calculated price for Durries according to customerdemand.

15) Number of Orders received: -It is revealed that they received 150 to 250 pieces of Durries order by the owner in amonth.

16) Show pre-production sample in front of customer: -It shows that 63.3 per cent respondents said that they show their pre-production sample in front of customer but only 36.7 per cent respondents said that they do not show any preproduction sample tocustomer.

17) Type of raw material use to make Durries: - It concluded that all the respondents were used Acrylic and polyesteryarns.

18) Type of loom use to make Durries: - It is described that 70 per cent respondents were used power looms to making Durries and only 30 per cent respondents were used handlooms tomakingDurries.

19) Type of tools use to make Durries: - It revealed that cent per cent respondents used combs, shuttle, rewinder, needles, cord, charkha, pirnetc.

\section{PLATE 2: Raw materials for making Durries}




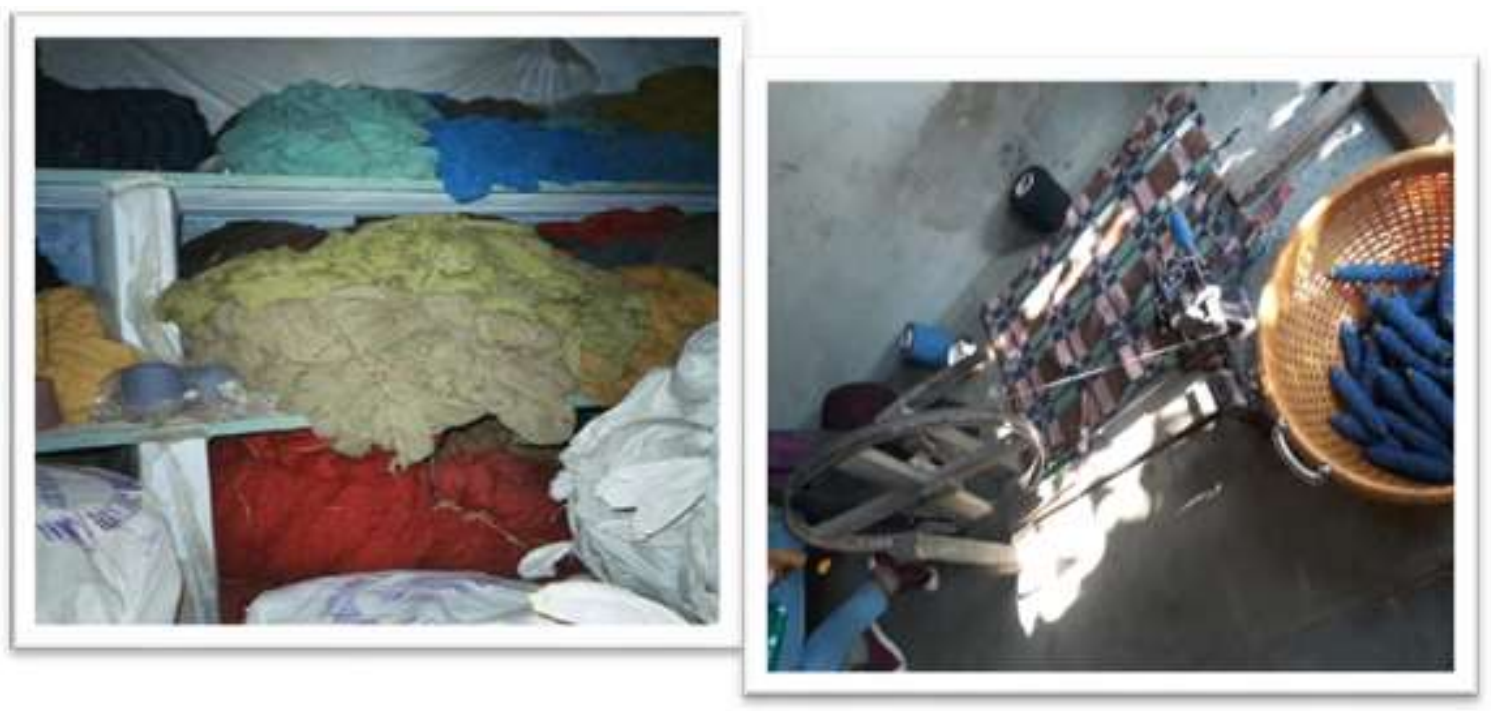

Hanksofyarns

Spinning of yarns oncharkha

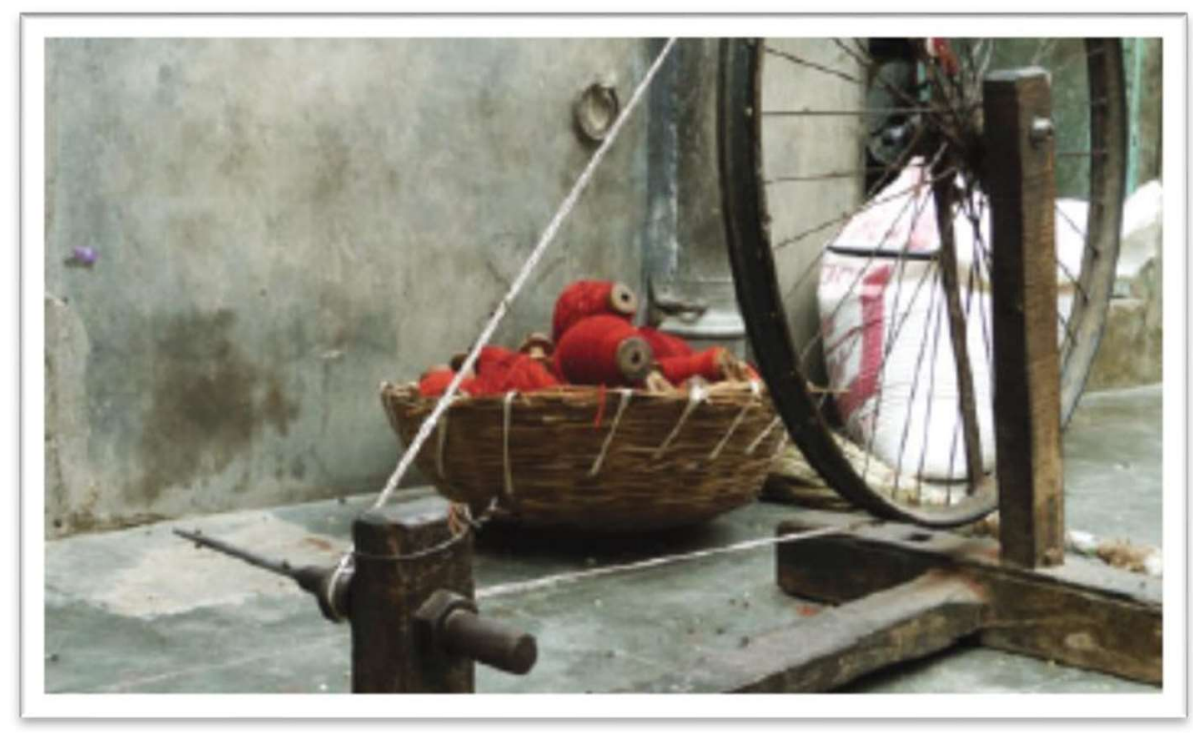

Charkha

PLATE: 3 Tools for making Durries 


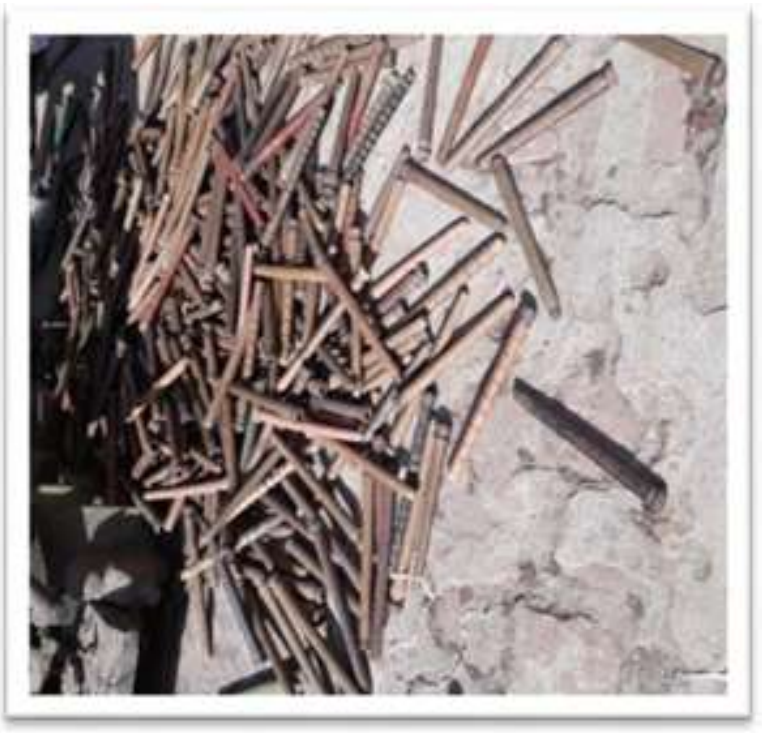

Pirn

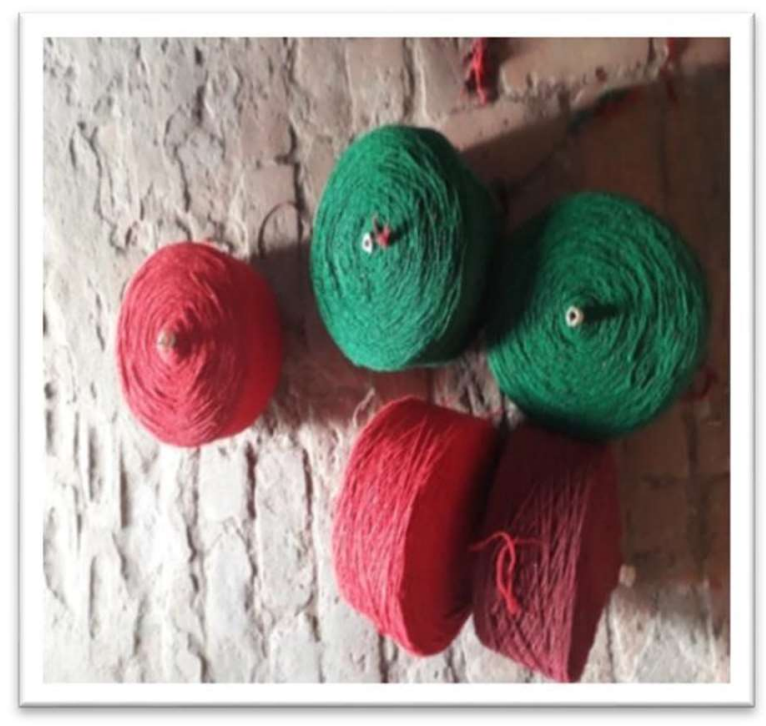

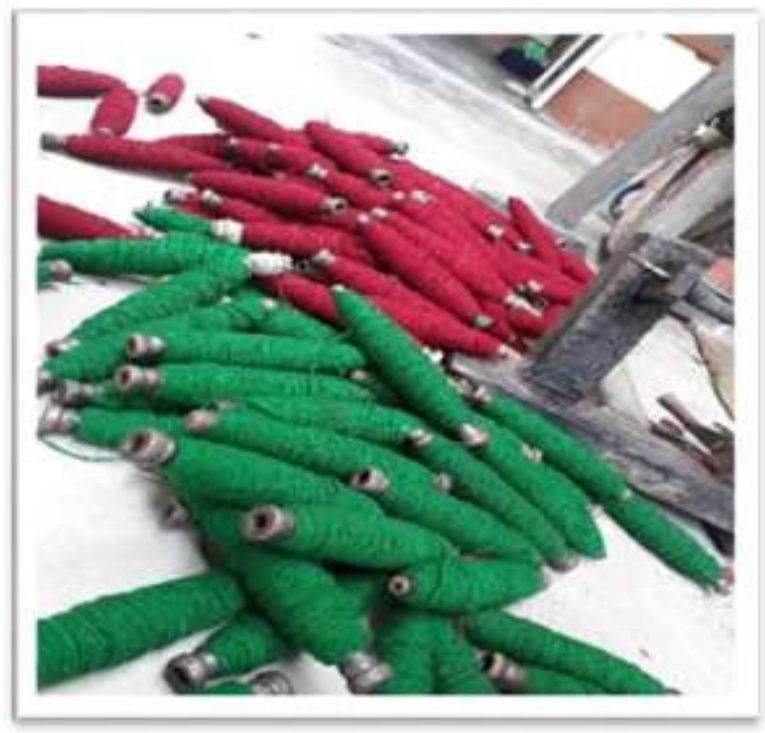

Twisted of yarns onPirn

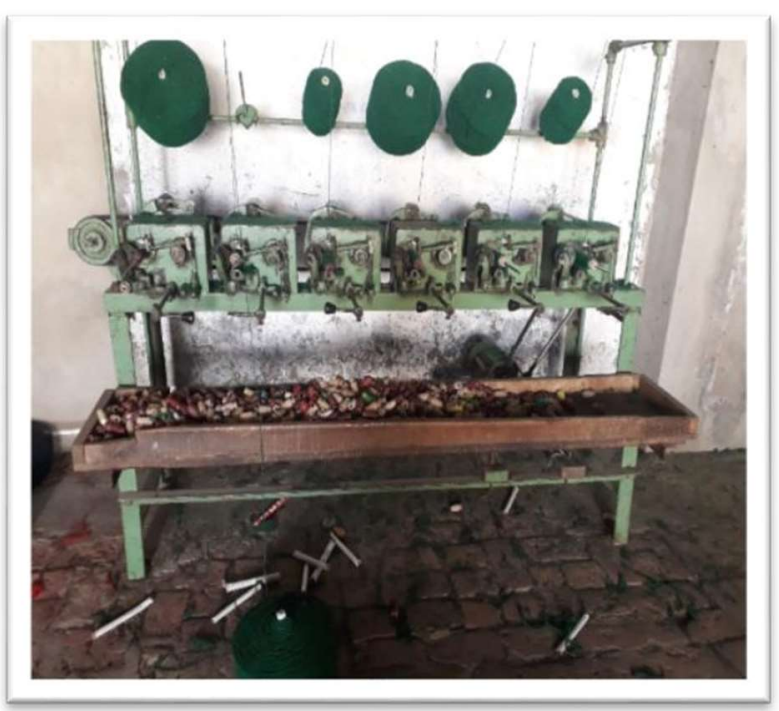

Blended Yarns Rewinding of yarns on power loom

PLATE 4: Types of looms

A)

Handloom 


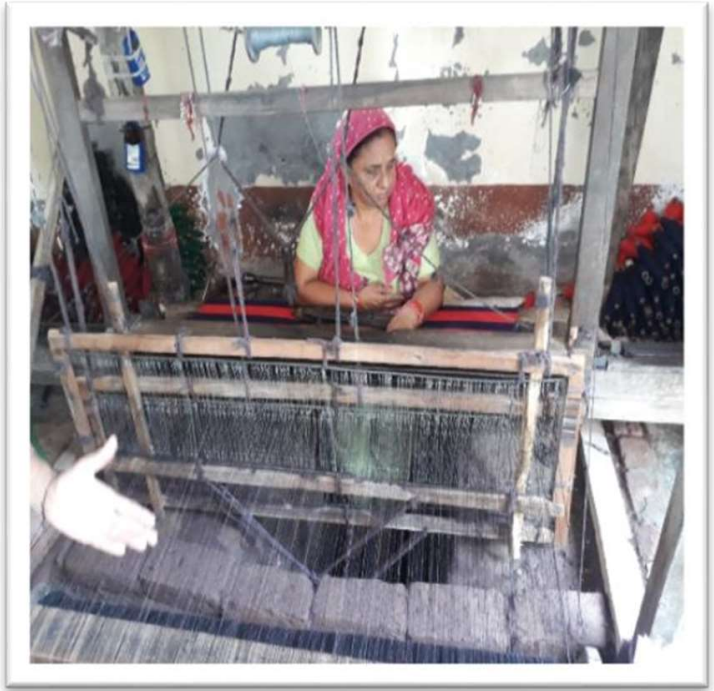

B)

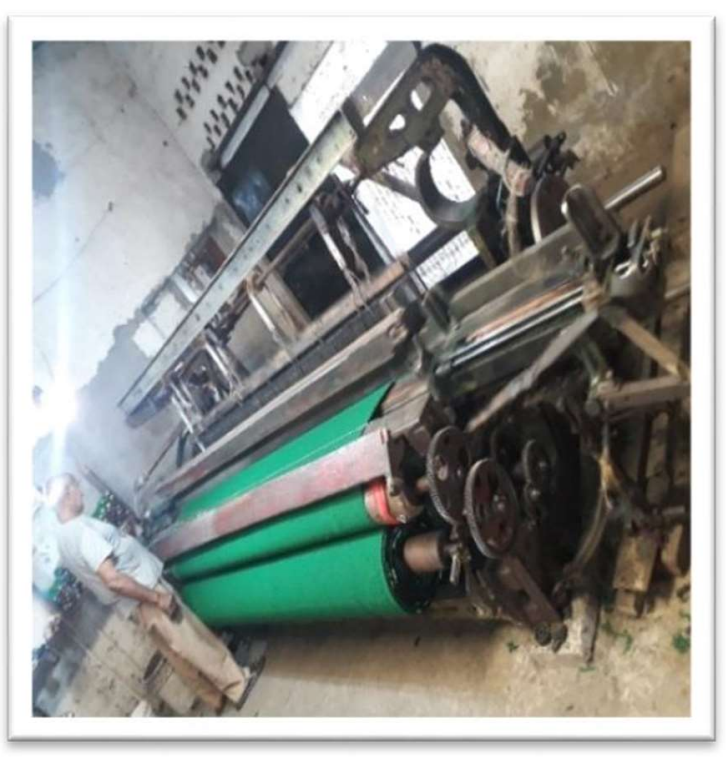

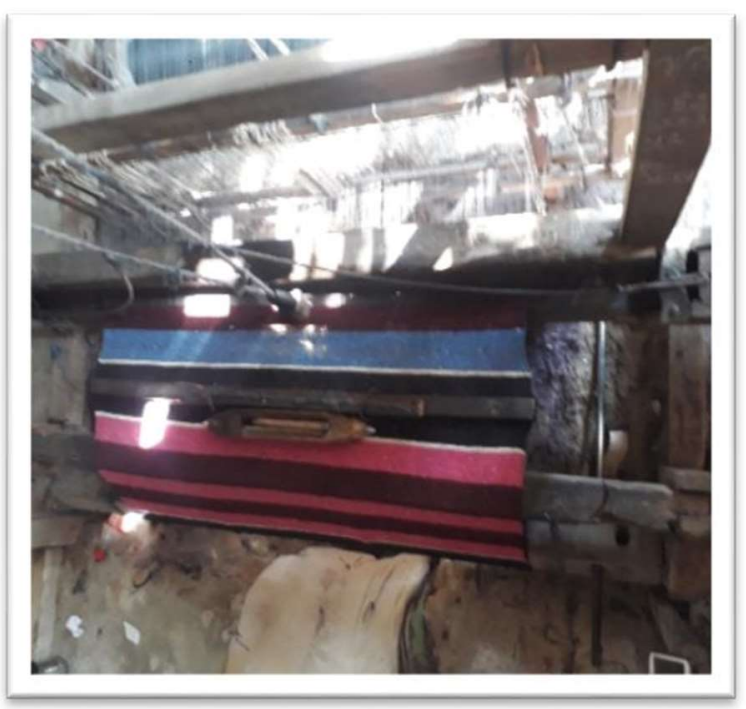

Powerloom

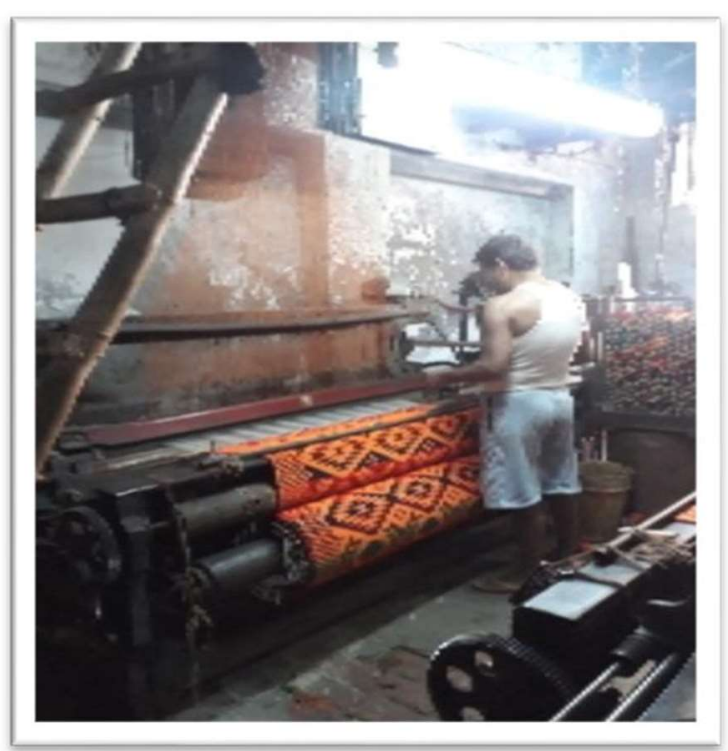




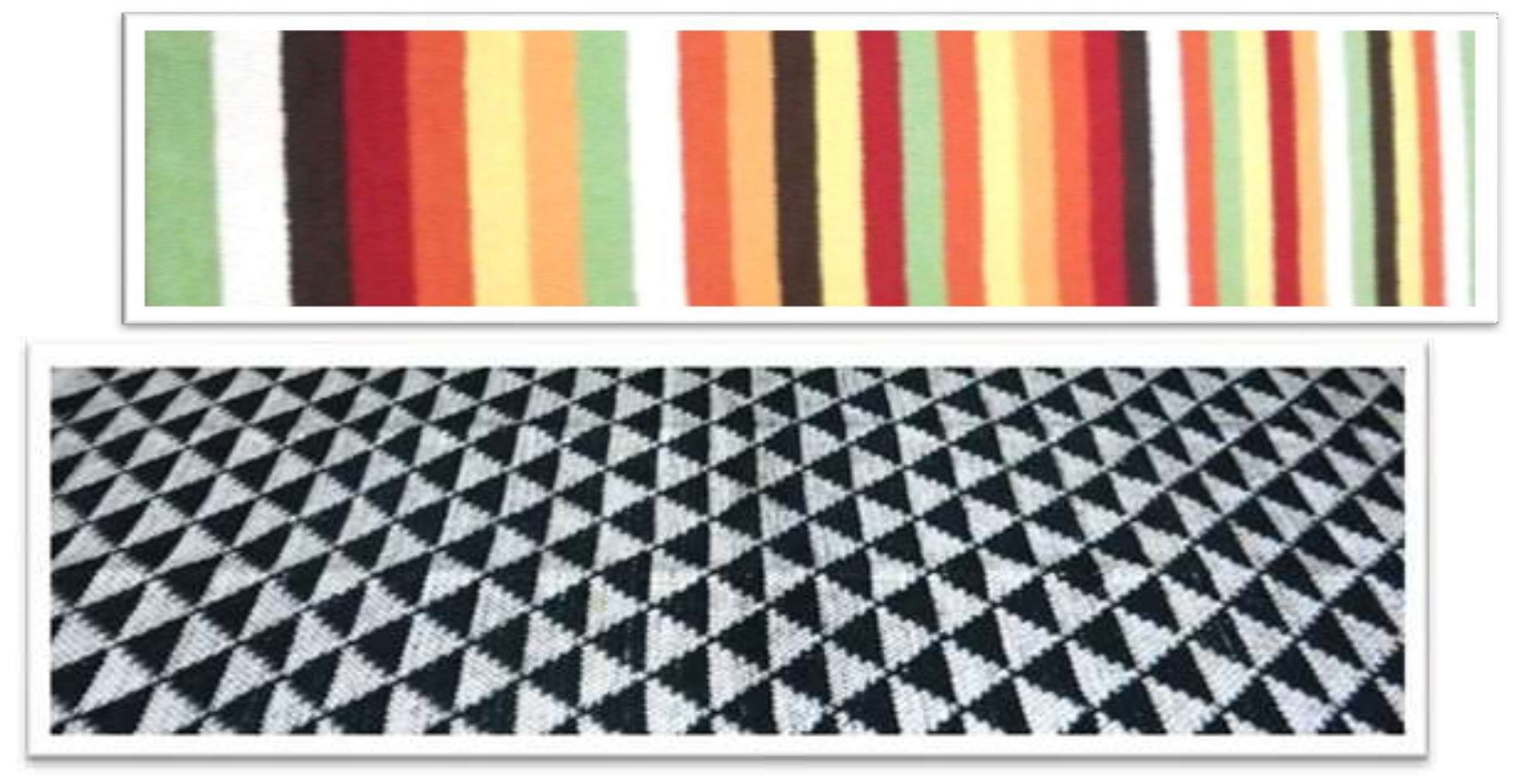

PLATE 5: Durries made on handloom

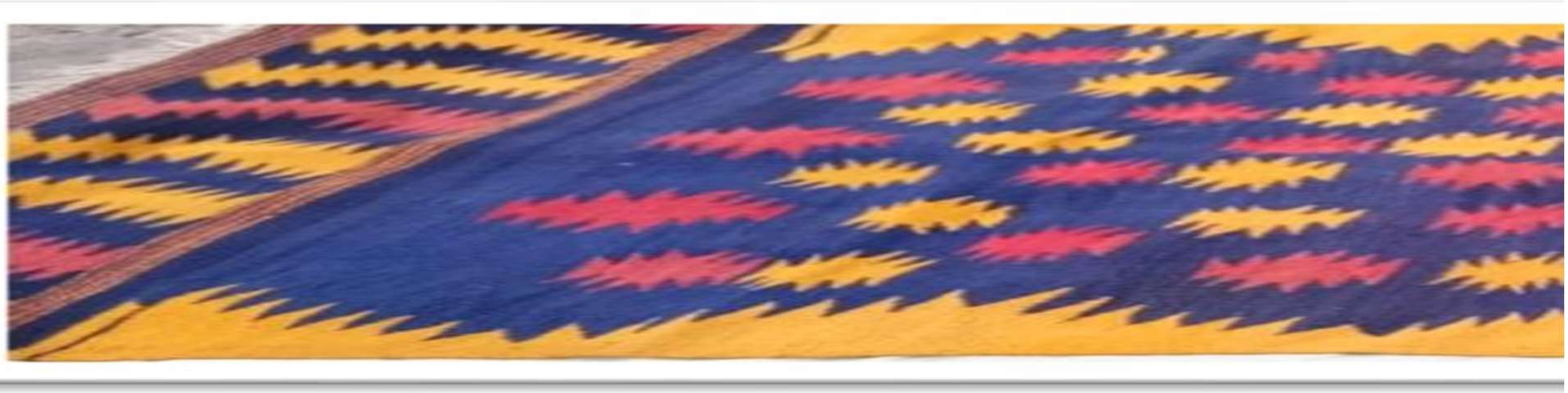

PLATE 6: Durries made on powerloom

Table 7:Distribution of Respondents on the basisto their finishing of Durries

$$
(\mathbf{n}=\mathbf{3 0})
$$

\begin{tabular}{|l|l|l|l|}
\hline \multicolumn{1}{|c|}{ S.No. } & \multicolumn{1}{|c|}{ Variables } & Respondents & \multicolumn{1}{c|}{ Percentage (\%) } \\
\hline 1. & Yes & 10 & $33.3 \%$ \\
\hline 2. & No & 20 & $66.7 \%$ \\
\hline & Total & $\mathbf{3 0}$ & $\mathbf{1 0 0 . 0 0}$ \\
\hline
\end{tabular}

Table 7 shows that 66.7 per cent respondents were not given finishing to Durries but only 33.3 per cent respondents were finished the Durries with knotting threads at the edges of Durries.

22) Selling of Durries in the National market: - It depicts that cent per cent respondents said that they sell their Durries in the National market to theirwholesaler. 


\section{CONCLUSIONS}

Durries making art is the oldest art of India. Thus it can be concluded that most of the craftsmen initiated this work from their young age. They had never taken any special training for making Durries. But they have learnt from forefathers' experience. As well as they spent 2 hours for making Durries. It is also found that they had never used any design for making Durries but they said that they used overall patterns in Durries. They were not given any special finishing to Durries but sometimes they finished Durries with knotting threads at the edges of Durries. According to craftsmen, they calculated the cost of Durries according to customer demand and sell their Durries in National market.

\section{REFERENCES}

1.Anonymous (2017)https://www.medium.com/@RugsandBeyond/handmade_rugs_and_durries_4957263898dd sited on 25 th August2019.

2. Mrunalini, A., and S. Logeswari. "Musculoskeletal problems of artisans in informal sector-a review study." Int J Environ, Ecology, Family and Urban Studies 6.1 (2016): 163-170.

3. Jayashankar (2001) krishikosh.egranth.ac.in/handle/1/5810049165, sited on $25^{\text {th }}$ August 2019.

4. Mitchell Beazly (1996) "Rugs \& Carpets - Techniques, Traditions andDesigns", Published by Andrew Middleton, Pp. 143 \& 150-151, sited on $8^{\text {th }}$ August2019.

5. Senthiil, P. V., VS Aakash Sirusshti, and T. Sathish. "Artificial intelligence based green manufacturability quantification of a unit production process." International Journal of Mechanical and Production Engineering Research and Development 9.2 (2019): 841-852.

6. R.M. LEHRI. (2009) "Indian Textiles -Ethnic beyond" Published on India, super book house, Mumbai. ISBN-978-81-9008098-9, Pp. 1-5, 15, sited on $8^{\text {th }}$ August2019.

7. Arbaeen, O., and Hind Mohammad. "Creating Contemporary Corset Designs, for Ladies' Clothing." International Journal of General Engineering and Technology (IJGET) 7.1 (2018): 21-34.

8. Shyam Ahuja (2019)http://www.shyamahuja.com/dhurrie-book.html, sited on 23 $3^{\text {rd }}$ August 2019.

9. Bori, Geetashree, and M. Neog Rupjyoti. "Emerging Trends in Woven Textile Fabrics Designs of Tribal Mising Community in Assam." International Journal of Applied and Natural Sciences (IJANS) 6.5 (2017): 7-14.

10. FATMA, TAYYABA, and SHRUTI SHARMA. "CONSUMER'S ACCEPTANCE AND MARKETABILITY OF DESIGNER BURQA." International Journal of Humanities and Social Sciences (IJHSS) ISSN(P): 2319-393X; ISSN(E): 2319-3948 Vol. 5 , Issue 2, Feb - Mar 2016, 1-16 
